\title{
A retroviral survey of endangered Eurasian lynx (Lynx lynx) from Croatia
}

\author{
Tomislav Gomerčić1, Matko Perharić ${ }^{2 *}$, Josip Kusak ${ }^{1}$, Vedran Slijepčević ${ }^{3}$, Vilim Starešina ${ }^{2}$, \\ Vladimir Stevanović ${ }^{2}$, Vesna Mojčec Perko ${ }^{2}$, Ira Topličanec ${ }^{1}$, and Magda Sindičićc ${ }^{4}$ \\ ${ }^{1}$ Department of Veterinary Biology, Faculty of Veterinary Medicine, University of Zagreb, Zagreb, Croatia \\ ${ }^{2}$ Department of Microbiology and Infectious Diseases with Clinic, Faculty of Veterinary Medicine, University of \\ Zagreb, Zagreb, Croatia
}

${ }^{3}$ Department of Wildlife Management and Nature Conservation, Karlovac University of Applied Sciences, Karlovac, Croatia

${ }^{4}$ Department for Game Biology, Pathology and Breeding, Faculty of Veterinary Medicine, University of Zagreb, Zagreb, Croatia

GOMERČIĆ, T., M. PERHARIĆ, J. KUSAK, V. SLIJEPČEVIĆ, V. STAREŠINA, V. STEVANOVIĆ, V. MOJČEC PERKO, I. TOPLIČANEC, M. SINDIČIĆ: A retroviral survey of endangered Eurasian lynx (Lynx lynx) from Croatia. Vet. arhiv 91, 65-71, 2021.

\section{ABSTRACT}

The feline immunodeficiency virus (FIV) and feline leukemia virus (FeLV) may cause persistent, lifelong and lethal infections in domestic and wild felids worldwide. FIV has been confirmed in most Felidae species, while FeLV infection is rare among non-domestic cats. The view that retroviruses are pathogenic in domestic cats but not in other free-ranging felid species was disproved by recent findings of retroviral pathology in several wild felids. The epidemiology of retroviral infections in felids in Croatia was only investigated in urban domestic cats, while there are no data for wild cat species. As the reintroduced Dinaric lynx (Lynx lynx) population suffers from low genetic diversity, which reduces their ability to adapt to new viral outbreaks, the health status of this lynx population is of particular concern. Two different commercial immunochromatographic assays were used for qualitative detection of FIV antibodies and FeLV antigens, while PCR was used for amplification of proviral gag and env genes in Eurasian lynx blood samples. All the 17 Eurasian lynx samples collected between 2001 and 2019 tested negative in both immunochromatographic and molecular tests. Even though our sample size was rather small, considering the fact that the population size of lynx in Croatia is estimated at 40 - 60 animals, our results can be considered representative for the population's health status. Also, data about retroviral prevalence in Eurasian lynxes are scarce, so any new findings are very valuable.

Key words: feline immunodeficiency virus; FIV; feline leukemia virus; FeLV; lynx

\section{Introduction}

Feline immunodeficiency virus (FIV) and feline leukemia virus (FeLV) are significant pathogens of domestic and wild felids worldwide. Both are enveloped RNA viruses, members of the Retroviridae family, where FIV is classified to the Lentivirus genus, while FeLV belongs to the Gamaretroviridae. Due to the enzyme reverse transcriptase and integration of the provirus into

\footnotetext{
*Corresponding author:

Matko Perharić, PhD, Department of Microbiology and Infectious Diseases with Clinic, Faculty of Veterinary Medicine, University of Zagreb, Heinzelova 55, 10000 Zagreb, Croatia, Phone:+385 12390 211; E-mail: mperharic@vef.hr
} 
the host cell genome, both viruses cause persistent, lifelong and potentially lethal infections. FIV causes progressive immune dysfunction due to a decrease in $\mathrm{CD}^{+}$T-lymphocytes, leading to acquired immunodeficiency syndrome (AIDS). FeLV infection usually causes bone marrow suppression, lymphoma or viral immunosuppression. Retroviral infected domestic cats may have a prolonged period with no clinical signs of the disease, but finally acquire life threatening secondary and opportunistic infections (BULL et al., 2003; HARTMANN, 2011; SELLON and HARTMANN, 2012).

FIV is mainly shed naturally in saliva and is transmitted through bite wounds. Beside bites, transplacental and veneral routes, colostrum and milk are also confirmed modes of FIV transmission (ROGERS and HOOVER, 2002; COATS, 2005; LEVY et al., 2006). FeLV transmission usually occurs through the oronasal route after close contact with salivary secretions, but viremic felids may also shed the virus in nasal secretions, faeces, urine and milk. Vertical transmission of FeLV has also been documented, as well as through cat fleas (PACITTI et al., 1986; VOBIS et al., 2003; GOMES-KELLER et al., 2009).

Both retroviral infections are endemic in domestic cat populations worldwide, with estimated FIV prevalence from 1 to $14 \%$ in cats without clinical signs, and up to $44 \%$ in cats expressing clinical symptoms (HARTMANN, 1998). The overall prevalence of FeLV in the mixed domestic cat population ranges from 1 to $6 \%$ (LEVY et al., 2006; GLEICH et al., 2009; HELLARD et al., 2011). FIV has been confirmed in most of the 37 Felidae species (review in O'BRIEN et al., 2012), while FeLV infection is rare among non-domestic cats. Phylogenetic results confirm that although FIV can occasionally move from species to species (TROYER et al., 2008), these events are rare, and most felids carry their own distinct version of the virus (LANGLEY et al., 1994; BARR et al., 1997; PECON-SLATTERY et al., 2008). In contrast, FeLV infections are mostly reported in captive animals that acquired the virus by physical contact with FeLV-infected domestic cats (KENNEDYSTOSKOPF, 1999; CUNNINGHAM et al., 2008).
Three felid species are present in Croatia - the domestic cat (Felis catus), the European wild cat (Felis silvestris silvestris) and the Eurasian lynx (Lynx lynx), but the epidemiological features of retroviral infections have only been investigated in domestic cats from the Zagreb urban area, confirming a high rate of FIV (18.51\%) and FeLV (14.5\%) seropositive cats (PERHARIĆ et al., 2018). So, the goal of our study was to determine the prevalence of retroviruses in the Eurasian lynx population in Croatia.

The size of the lynx population in Croatia today is estimated at 40 - 60 individuals, all of them being offspring of six individuals reintroduced from Slovakia to the Dinaric Mountains in 1973 (SINDIČIĆ et al. 2016). The health status of the reintroduced Dinaric lynx population is of particular concern, because the population suffers from low genetic diversity and inbreeding depression (SINDIČIĆ et al., 2013). Decreased genetic diversity in wild populations reduces the ability to adapt to new viral outbreaks, such as wellknown cases of coronavirus in cheetahs (PEARKS WILKERSON et al., 2004) or different infectious diseses in Iberian lynxes (LÓPEZ et al., 2014).

\section{Materials and methods}

The research was performed on 17 wild and captured Eurasian lynx (Lynx lynx) blood samples. The animals were sampled in Croatia, in the areas of Gorski kotar and Lika (Fig. 1), in the period from 2001 to 2019. The animals were captured and equipped with radio collars for activity and movement research, except one animal that was found in the vicinity of an urban area, with an injured leg and malnourished. This subadult male lynx died the day after it was captured, with purulent necrotic hepatitis and septicaemia found at necropsy. Apart from this subadult, all the animals were adults, 6 were females and 11 males.

Blood samples were collected from the vena cephalica antebrachi or v. saphena into EDTAcoated tubes by an aseptic method. Retroviral status was initially analyzed by two different commercial immunochromatographic assays - FASTest ${ }^{\circledR}$ FeLVFIV, MEGACOR Diagnostik GmbH and IDEXX SNAP Combo Plus, IDEXX Laboratories. Both 


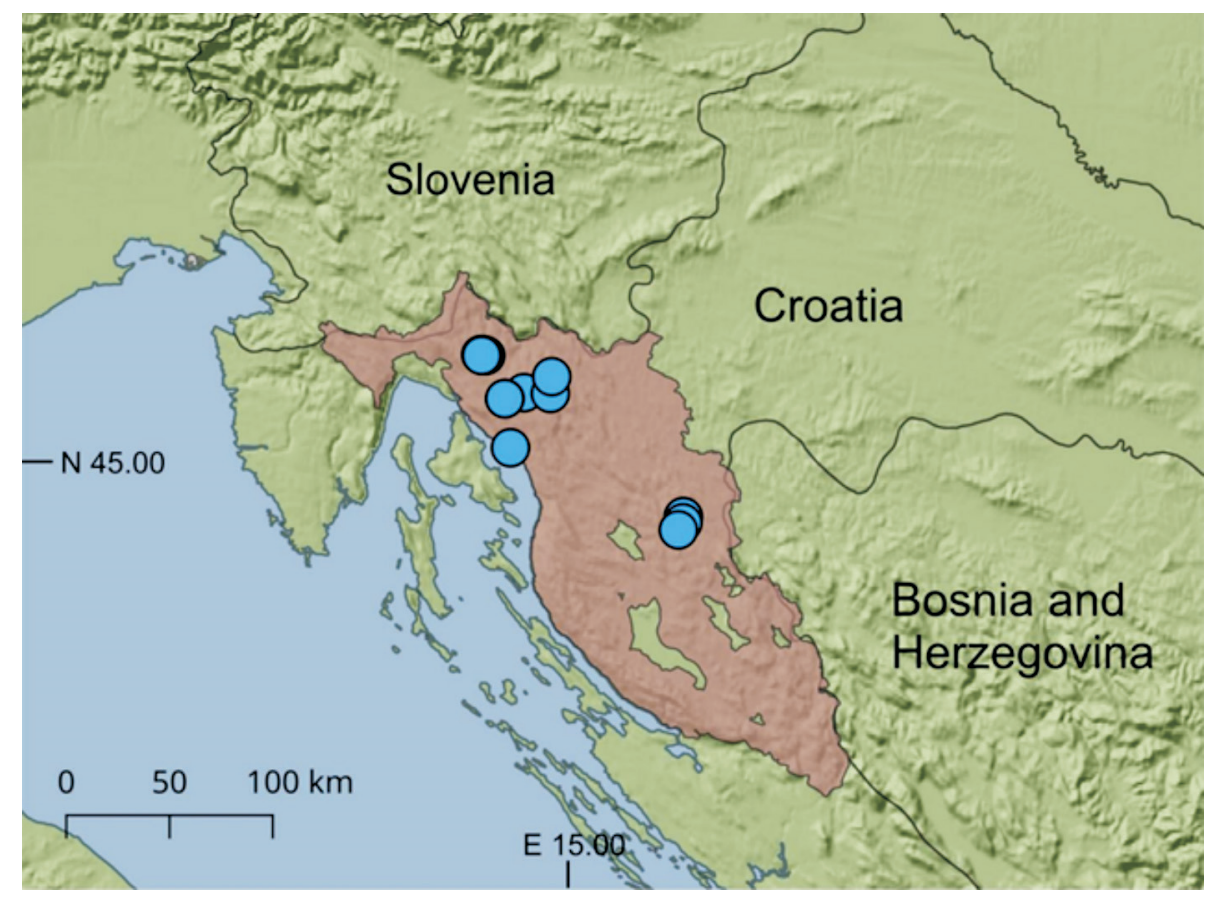

Fig. 1. Map of Croatia, with the brown area indicating Eurasian lynx distribution, and blue dots indicating sampling locations

tests are used for qualitative detection of FIV antibodies for FIV gp40 trans-membrane protein, and qualitative detection of FeLV p27 specific antigens in the whole blood, plasma or serum. The reported sensitivity and specificity for domestic cats for FASTest ${ }^{\circledR}$ FIV were $96.4 \%$ and $99.2 \%$, and for FASTest ${ }^{\circledR}$ FeLV $94.7 \%$ and $98.8 \%$ (HARTMANN et al., 2007). Similar results were published for IDEXX SNAP Combo, sensitivity and specificity for FIV infection were $100 \%$ and $99.6 \%$, and for FeLV $92.3 \%$ and $97.3 \%$ (HARTMANN et al., 2007). Both diagnostic assays were performed according to the manufacturer's instructions.

Prior to molecular diagnostic for FIV and FeLV, DNA was extracted from EDTA-treated lynx whole blood. A commercially available QIAamp DNA Mini Kit (Qiagen, Hilden, Germany) was used for DNA extraction. Molecular diagnostics for FIV infection were performed with two different PCR protocols. For detection of proviral gag gene primers FIV-1026F ( $5^{\prime}$ - GGC ATA TCC TAT TCA ACC AG - 3') and FIV 1700R (5' - AAG AGT TGC ATT TTA TAT CC - $3^{\prime}$ ) were used for amplification (CAMMAROTA et al., 1996; STEINRIGL and
KLEIN, 2003). The second PCR protocol was used for proviral env gene detection with primers FIV7316F (5' - ATA CCA AAA TGT GGA TGG TG $\left.3^{\prime}\right)$ and FIV-7868R (5' - TGC AAG ACC AAT TTC CAG CA - 3') (STEINRIGL and KLEIN, 2003). For FeLV infection nested PCR was performed for gag gene amplification. The first set of primers (outer primers) was U3-F1 (5' - ACA GCA GAA GTT TCA ACG CC - 3') and G-R1 (5' - GAC CAG TGA TCAAGG GTG AG - 3'). The PCR product of this first round served as a template for the second round of PCR with nested primers U3-F2 (5' - GCT CCC CAG TTG ACC AGA GT - 3') and G-R2 (5' - GCT TCG GTA CCA AAC CGA AA - 3') (KAEWMONGKOL et al., 2007). For both FIV and $\mathrm{FeLV}$, agarose gel electrophoresis was performed to visualize the PCR product.

\section{Results and discussion}

All 17 Eurasian lynx tested negative for FIV and FeLV using two different immunochromatographic assays. The FIV proviral gag and env genes, and the FeLV proviral gag gene were not amplified in any of the 17 samples. Even though our sample 
size was rather small, considering the fact that the population size of lynx in Croatia is estimated at 40 - 60 animals, our results can be considered representative for the population health status. Also, data about retroviral prevalence in Eurasian lynx are scarce so any new finding is very valuable. The only available data are serological tests for FeLV in free ranging and captive animals from Sweden, and FeLV and FIV in free ranging lynxes from Switzerland, which were all negative (LUTZ et al., 1992; RYSER-DEGIORGIS et al., 2005).

Most data about the retroviral status of lynx in Europe come from Spain, where there is an endangered Iberian lynx (Lynx pardinus) population. Theabsence of FIV antibodies was reported in Iberian lynxes sampled between 1989 and 2007 (ROELKE et al., 2008; LUACES et al., 2008; MILLÁN et al., 2009, MELI et al., 2009), and confirmed by qPCR on 311 individuals sampled between 2004 and 2017 (LOPEZ et al., 2019). Beside negative molecular tests, one animal tested positive for FIV antibodies by ELISA and immunoblot assay, but showed no signs of the disease (LOPEZ et al., 2019). In contrast, an FeLV epidemic caused the death of six Iberian lynxes in 2007, while in the same period an additional seven lynxes were found to be FeLVpositive and survived. Several of the FeLV-infected lynxes showed clinical signs and/or hematological abnormalities, such as anemia, lymphopenia or neutropenia, compatible with the FeLV infection also observed in domestic cats (MELI et al., 2009). As only a few cases of FeLV infection were observed prior to 2007 (LUACES et al., 2008), it is likely that FeLV infection is rare in lynxes, is not readily carried within the lynx population, and most likely originates from domestic cats (MELI et al., 2009). GERET et al. (2011) suggest that the severe outcome of the FeLV outbreak in 2007 was due to the particular susceptibility of the Iberian lynx to pathogens. The Iberain lynx population suffers from reduced genetic variability (JOHNSON et al., 2004), as does our Dinaric lynx population, which underlines the need for regular monitoring of the retroviral status of the population.

The importance of regular monitoring of retroviruses in felids has also been underlined in recent publications. Originally, the absence of clear clinical pathology among infected felids fostered the view that retroviruses are pathogenic in domestic cats but not in other free ranging felid species (CARPENTER and O'BRIEN, 1995; PACKER et. al., 1999; O'BRIEN et al., 2012). However, new findings strongly suggest that FIV is contributing to the loss of immune competence in infected lions (ROELKE et al., 2009), while FeLV was proved as a cause of death in Iberain lynxes in 2007 (MELI et al., 2009), and Florida panthers in 2001-2006 (CUNNINGHAM et al., 2008).

\section{References}

BARR, M. C., L. ZOU, F. LONG, W. A. HOOSE, R. J. AVERY (1997): Proviral organization and sequence analysis of feline immunodeficiency virus isolated from a Pallas' cat. Virology 228, 84-91.

DOI: $10.1006 /$ viro.1996.8358

BULL, M. E., S. KENNEDY-STOSKOPF, J. F. LEVINE, M. LOOMIS, D. G. GEBHARD, W. A. F. TOMPKINS (2003): Evaluation of T lymphocytes in captive African lions (Panthera leo) infected with feline immunodeficiency virus. Am. J. Vet. Res. 64, 1293-1300.

DOI: 10.2460/ajvr.2003.64.1293

CAMMAROTA, G., L. DA PRATO, E. NICOLETTI, D. MATTEUCCI, M. BENDINELLI, M. PISTELLO (1996): Quantitation of feline immunodeficiency proviruses in doubly infected cats using competitive PCR and a fluorescence-based RFLP. J. Virol. Methods 62, 21-31. DOI: 10.1016/0166-0934(96)02085-X

CARPENTER, M. A., S. J. O'BRIEN (1995): Coadaptation and immunodeficiency virus: lessons from the Felidae. Curr. Opin. Genet. Dev. 5, 739-745.

DOI: 10.1016/0959-437X(95)80006-Q

COATS, K. S. (2005): The feline immunodeficiency virusinfected cat: A model for lentivirus-induced placental immunopathology and reproductive failure (mini-review). Am. J. Reprod. Immunol. 54, 169-185.

DOI: 10.1111/j.1600-0897.2005.00296.x

CUNNINGHAM, M. W., M. A. BROWN, D. B. SHINDLE, S. P. TERRELL, K. A. HAYES, B. C. FERREE, R. T. MCBRIDE, E. L. BLANKENAHIP, D. JANSEN, S. B. CITINO, M. E. ROELKE, R. A. KILTIE, J. L. TROYER, S. J. O'BRIEN (2008): Epizootiology and management of feline leukemia virus in the Florida puma. J. Wildl. Dis. 44, 537-552.

DOI: $10.7589 / 0090-3558-44.3 .537$

GERET, C. P., V. CATTORI, M. L. MELI, B. RIOND, F. MARTÍNEZ, G. LÓPEZ, A. VARGAS, M. A. SIMÓN, J. V. LÓPEZ-BAO, R. HOFMANN-LEHMANN, H. LUTZ (2011): Feline leukemia virus outbreak in the critically endangered Iberian lynx (Lynx pardinus): High-throughput sequencing of envelope variable region A and experimental transmission. Arch. Virol. 156, 839-854. 
DOI: $10.1007 / \mathrm{s} 00705-011-0925-\mathrm{z}$

GLEICH, S. E., S. KRIEGER, K. HARTMANN (2009): Prevalence of feline immunodeficiency virus and feline leukaemia virus among client-owned cats and risk factors for infection in Germany. J. Feline Med. Surg. 11, 985-992. DOI: $10.1016 /$ j.jfms.2009.05.019

GOMES-KELLER, M. A., E. GÖNCZI, B. GRENACHER, R. TANDON, R. HOFMAN-LEHMANN, H. LUTZ (2009): Fecal shedding of infectious feline leukemia virus and its nucleic acids: A transmission potential. Vet. Microbiol. 134, 208-217.

DOI: 10.1016/j.vetmic.2008.08.011

HARTMANN, K. (1998): Feline immunodeficiency virus infection: An overview. Vet. J. 155, 123-137. DOI: 10.1016/S1090-0233(98)80008-7

HARTMANN, K., P. GRIESSMAYR, B. SCHULZ, C. E. GREENE, A. N. VIDYASHANKAR, O. JARRETT, H. F. EGBERINK (2007): Quality of different in-clinic test systems for feline immunodeficiency virus and feline leukaemia virus infection. J. Feline Med. Surg. 9, 439-445. DOI: $10.1016 /$ j.jfms.2007.04.003

HARTMANN, K. (2011): Clinical aspects of feline immunodeficiency and feline leukemia virus infection. Vet. Immunol. Immunopathol. 143, 190-201.

DOI: $10.1016 /$ j.vetimm.2011.06.003

HELLARD, E., D. FOUCHET, H. SANTIN-JANIN, B. TARIN, V. BADOL, C. COUPIER, G. LEBLANC, H. POULET, D. PONTIER (2011): When cats' ways of life interact with their viruses: A study in 15 natural populations of owned and unowned cats (Felis silvestris catus). Prev. Vet. Med. 101, 250-264.

DOI: $10.1016 /$ j.prevetmed.2011.04.020

JOHNSON, W. E., J. A. GODOY, F. PALOMARES, M. DELIBES, M. FERNANDES, E. REVILLA, S. J. O'BRIEN (2004): Phylogenetic and phylogeographic analysis of Iberian lynx populations. J. Hered. 95, 19-28. DOI: $10.1093 /$ jhered/esh006

KAEWMONGKOL, G., K. THAINGTUM, T. SIRINARUMITR (2007): Development of nested polymerase chain reaction for diagnosis of FeLV infection in cats. Kasetsart J. (Nat. Sci.) 41, 91-96.

KENNEDY-STOSKOPF, S. (1999): Emerging viral infections in large cats. In: Zoo and Wild Animal Medicine (Fowler, M. E., R. E. Miller, Eds.), W. B. Saunders, Philadelphia, pp. 401-410.

LUACES, I., A. DOMÉNECH, M. GARCÍA-MONTIJANO, V. M. COLLADO, C. SÓNCHEZ, J. G. TEJERIZO, M. GALKA, P. FERNÓNDEZ, E. GÓMEZ-LUCÍA (2008): Detection of Feline Leukemia Virus in the endangered Iberian Lynx (Lynx pardinus). J. Vet. Diagn. Invest. 20, 381-385.

DOI: $10.1177 / 104063870802000325$

LANGLEY, R. J., V. M. HIRSCH, S. J. O'BRIEN, D. ADGERJOHNSON, R. M. GOEKEN, R. A. OLMSTED (1994): Nucleotide sequence analysis of Puma Lentivirus (PLV-
14): Genomic organization and relationship to other Lentiviruses. Virology 202, 853-864.

DOI: 10.1006/viro.1994.1407

LEVY, J. K., H. M. SCOTT, J. L. LACHTARA, P. C. CRAWFORD (2006): Seroprevalence of feline leukemia virus and feline immunodeficiency virus infection among cats in North America and risk factors for seropositivity. J. Am. Vet. Med. Assoc. 228, 371-376.

DOI: $10.2460 /$ javma.228.3.371

LÓPEZ, G., M. LÓPEZ-PARRA, G. GARROTE, L. FERNÁNDEZ, T. DEL REY-WAMBA, R. ARENASROJAS, M. GARCÍA-TARDÍO, G. RUIZ, I. ZORRILLA, M. MORAL, M. A. SIMÓN (2014): Evaluating mortality rates and causalities in a critically endangered felid across its whole distribution range. Eur. J. Wildl. Res. 60, 359366.

DOI: $10.1007 / \mathrm{s} 10344-013-0794-8$

LÓPEZ, G., T. DEL REY-WAMBA, B. WILLET, L. FERNÁNDEZ-PENA, M. LÓPEZ-PARRA, C. I. LEÓN, R. C. SERRA, I. ZORRILLA, R. HOFMANNLEHMANN, M. A. SIMÓN, M. L. MELI (2019): Lack of contact with feline immunodeficiency virus in the Iberian lynx. Eur. J. Wildl. Res. 65, 4.

DOI: $10.1007 / \mathrm{s} 10344-018-1247-1$

LUACES, I., A. DOMÉNECH, M. GARCÍA-MONTIJANO, V. M. COLLADO, C. SÁNCHEZ, J. G. TEJERIZO, M. GALKA, P. FERNÁNDEZ, E. GÓMEZ-LUCÍA (2008): Detection of Feline leukemia virus in the endangered Iberian lynx (Lynx pardinus). J. Vet. Diagnostic Investig. 20, 381-385.

DOI: $10.1177 / 104063870802000325$

LUTZ, H., E. ISENBÜGEL, R. LEHMANN, R. H. SABAPARA \& C. WOLFENSBERGER (1992): Retrovirus infections in non-domestic felids: serological studies and attempts to isolate a lentivirus. Vet. Immunol. Immunopathol. 35, 215-224.

DOI: 10.1016/0165-2427(92)90133-B

MELI, M. L., V. CATTORI, F. MARTÍNEZ, G. LÓPEZ, A. VARGAS, M. A. SIMÓN, I. ZORRILLA, A. MUÑOZ, F. PALOMARES, J. V. LÓPEZ-BAO, J. PASTOR, R. TANDON, B. WILLI, R. HOFMANN-LEHMANN, H. LUTZ (2009): Feline leukemia virus and other pathogens as important threats to the survival of the critically endangered Iberian lynx (Lynx pardinus). PLoS One 4, 4744.

DOI: 10.1371/journal.pone.0004744

MilláN, J., M. G. CANDELA, F. PALOMARES, M. J. CUBERO, A. RODRÍGUEZ, M. BARRAL, J. DE LA FUENTE, S. ALMERÍA, L. LEÓN-VIZCAÍNO (2009): Disease threats to the endangered Iberian lynx (Lynx pardinus). Vet. J. 182, 114-124.

DOI: $10.1016 / j . t v j 1.2008 .04 .005$

O'BRIEN, S. J., J. L. TROYER, M. A. BROWN, W. E. JOHNSON, A. ANTUNES, M. E. ROELKE, J. PECONSLATTERY (2012): Emerging viruses in the felidae: Shifting paradigms. Viruses 4, 236-257. 
DOI: $10.3390 / \mathrm{v} 4020236$

PACITTI, A. M., O. JARRETT, D. HAY (1986): Transmission of feline leukaemia virus in the milk of a non-viraemic cat. Vet. Rec. 118, 381-384.

DOI: $10.1136 / v r .118 .14 .381$

PACKER, C., S. ALTIZER, M. APPEL, E. BROWN, J. MARTENSON, S. J. O'BRIEN, M. ROELKE-PARKER, R. HOFMANN-LEHMANN, H. LUTZ (1999): Viruses of the Serengeti: Patterns of infection and mortality in African lions. J. Anim. Ecol. 68, 1161-1178.

DOI: $10.1046 / \mathrm{j} .1365-2656.1999 .00360 . \mathrm{x}$

PEARKS WILKERSON, A. J., E. C. TEELING, J. L. TROYER, G. K. BAR-GAL, M. ROELKE, L. MARKER, J. PECONSLATTERY, S. J. O'BRIEN (2004): Coronavirus outbreak in cheetahs: Lessons for SARS. Curr. Biol. 14, 227-228. DOI: 10.1016/j.cub.2004.02.051

PECON-SLATTERY, J., C. L. MCCRACKEN, J. L. TROYER, S. VANDEWOUDE, M. ROELKE, K. SONDGEROTH, C. WINTERBACH, H. WINTERBACH, S. J. O'BRIEN (2008): Genomic organization, sequence divergence, and recombination of feline immunodeficiency virus from lions in the wild. BMC Genomics 9, 66 .

DOI: 10.1186/1471-2164-9-66

PERHARIĆ, M., V. STAREŠINA, N. TURK, L. BARBIĆ, Z. ŠTRITOF, S. HAĐINA, J. HABUŠ, V. STEVANOVIĆ, K. MARTINKOVIĆ, V. M. PERKO, Z. MILAS (2018): The epidemiology features of retroviral infections in domestic cats from the Zagreb urban area. Vet. arhiv 88, 345-354. DOI: 10.24099/vet.arhiv.170406b

ROELKE, M. E., M. A. BROWN, J. L. TROYER, H. WINTERBACH, C. WINTERBACH, G. HEMSON, D. SMITH, R. C. JOHNSON, J. PECON-SLATTERY, A. L. ROCA, K. A. ALEXANDER, L. KLEIN, P. MARTELLI, K. KRISHNASAMY, S. J. O'BRIEN (2009): Pathological manifestations of feline immunodeficiency virus (FIV) infection in wild African lions. Virology 390, 1-12.

DOI: 10.1016/j.virol.2009.04.011

ROELKE, M. E., W. E. JOHNSON, J. MILLÁN, F. PALOMARES, E. REVILLA, A. RODRÍGUEZ, J. CALZADA, P. FERRERAS, L. LEÓN-VIZCAÍNO, M. DELIBES, S. J. O'BRIEN (2008): Exposure to disease agents in the endangered Iberian lynx (Lynx pardinus). Eur. J. Wildl. Res. 54, 171-178.

DOI: $10.1007 / \mathrm{s} 10344-007-0122-2$
ROGERS, A. B., E. A. HOOVER (2002): Fetal feline immunodeficiency virus is prevalent and occult. J. Infect. Dis. $186,895-904$.

DOI: $10.1086 / 344173$

RYSER-DEGIORGIS, M. P., R. HOFMANN-LEHMANN, C. M. LEUTENEGGER, C. H. AF SEGERSTAD, T. MÖRNER, R. MATTSSON, H. LUTZ (2005): Epizootiologic investigations of selected infectious disease agents in free-ranging Eurasian lynx from Sweden. J. Wildl. Dis. 41, 58-66.

DOI: $10.7589 / 0090-3558-41.1 .58$

SELLON, R. K., K. HARTAMNN (2012): Feline immunodeficiency virus infection. In: Infectious diseases of the dog and cat, $4^{\text {th }}$ ed. (Greene, C. E., Ed.), Elsevier, Saunders: St Louis, MO, USA. pp. 136-149.

SINDIČIĆ, M., T. GOMERČIĆ, J. KUSAK, V. SLIJEPČEVIĆ, D. HUBER, A. FRKOVIĆ (2016): Mortality in the Eurasian lynx population in Croatia during the 40 years. Mamm. Biol. 81, 290-294.

DOI: 10.1016/j.mambio.2016.02.002

SINDIČIĆ, M., P. POLANC, T. GOMERČIĆ, M. JELENČIČ, D. HUBER, P. TRONTELJ, T. SKRBINŠEK (2013): Genetic data confirm critical status of the reintroduced Dinaric population of Eurasian lynx. Conserv. Genet. 14, 1009-1018.

DOI: $10.1007 / \mathrm{s} 10592-013-0491-\mathrm{x}$

STEINRIGL, A., D. KLEIN (2003): Phylogenetic analysis of feline immunodeficiency virus in Central Europe: A prerequisite for vaccination and molecular diagnostics. J. Gen. Virol. 84, 1301-1307.

DOI: 10.1099/vir.0.18736-0

TROYER, J. L., S. VANDEWOUDE, J. PECON-SLATTERY, C. MCINTOSH, S. FRANKLIN, A. ANTUNES, W. JOHNSON, S. J. O'BRIEN (2008): FIV cross-species transmission: An evolutionary prospective. Vet. Immunol. Immunopathol. 123, 159-166.

DOI: $10.1016 /$ j.vetimm.2008.01.023

VOBIS, M., J. D'HAESE, H. MEHLHORN, N. MENCKE (2003): Evidence of horizontal transmission of feline leukemia virus by the cat flea (Ctenocephalides felis). Parasitol. Res. 91, 467-470.

DOI: $10.1007 / \mathrm{s} 00436-003-0949-8$

Received: 28 October 2019

Accepted: 21 May 2020 
GOMERČIĆ, T., M. PERHARIĆ, J. KUSAK, V. SLIJEPČEVIĆ, V. STAREŠINA, V. STEVANOVIĆ, V. MOJČEC PERKO, I. TOPLIČANEC, M. SINDIČIĆ: Istraživanje retrovirusnih infekcija u ugroženoj populaciji euroazijskog risa (Lynx lynx) u Hrvatskoj. Vet. arhiv 91, 65-71, 2021.

\section{SAŽETAK}

Virus mačje imunodeficijencije (FIV) i virus mačje leukemije (FeLV) mogu uzrokovati trajne, cjeloživotne i smrtne infekcije u domaćih i divljih felida širom svijeta. FIV je potvrđen u većine felida, dok je infekcija FeLV-om u domaćih mačaka rijetka. Mišljenje da su retrovirusi patogeni u domaćih mačaka, ali ne i u slobodnoživućih felida, opovrgnuto je najnovijim istraživanjima retrovirusne patologije u nekoliko divljih felida. Epidemiologija retrovirusnih infekcija u felida u Hrvatskoj istraživana je u gradskih domaćih mačaka, dok podaci za divlje mačke ne postoje. Kako populaciju reintroduciranog dinarskog risa ( Lynx lynx) obilježava niska genetska raznolikost, što smanjuje mogućnost prilagodbe na nove virusne zaraze, postoji osobita zabrinutost za zdravstveno stanje ove populacije risa. U radu su upotrijebljene dvije različite komercijalne imunokromatografske pretrage za kvalitativnu detekciju protutijela na FIV i FeLV antigene, dok je PCR upotrijebljen za umnažanje provirusnih gena gag i env u uzorcima krvi euroazijskog risa. Svih 17 uzoraka euroazijskog risa, prikupljenih od 2001. do 2019., bilo je negativno i u imunokromatografskom i molekularnom testu. Iako se radi o maloj veličini uzorka, s obzirom na to da je veličina populacije risa u Hrvatskoj procijenjena na 40 - 60 jedinki, naši se uzorci mogu smatrati reprezentativnima za zdravstveni status navedene populacije. Također, malo je podataka o retrovirusnoj prevalenciji u euroazijskog risa, što novim podacima dobivenim ovim istraživanjem daje dodatnu vrijednost.

Ključne riječi: virus mačje imunodeficijencije; FIV; virus mačje leukemije; FeLV; ris 
